\title{
Eucaristía
}

\section{Compartir en solidaridad con la humanidad hambrienta, sedienta, pobre y sufriente}

\author{
Juan Hernández Pico, \\ Centro de Reflexión Teológica, \\ San Salvador.
}

\section{El hambre y la sed: las más terribles experiencias de la humanidad}

\subsection{En el Antiguo Testamento}

Nada hay más horrendo para la humanidad que la experiencia del hambre y de la sed. Por supuesto, la tortura puede ser más espantosa, pero normalmente es un sufrimiento infligido a minorías, aunque también el hambre y la sed pueden ser infligidas como tortura o componente de la tortura. El hambre y la sed a que nos referimos aquí es un asunto de mayorías. Esa experiencia configura lo más hondo de la pobreza y del sufrimiento humanos, la miseria.

Durante los famosos siete años bíblicos de "hambre que hará olvidar la abundancia" (Gn 41, 30), Jacob envía a sus hijos a Egipto para comprar grano con el que vivir y no morir (Gn 42,1-2). José obliga a sus hermanos a venir con el menor de ellos y con su propio padre a un imperio egipcio que se ha librado de la escasez por la prudente política del primer ministro israelita del faraón. No importa aquí tanto lo que sean las huellas de la historia, como las experiencias mítico-vivenciales acendradas en la memoria histórica del pueblo de Israel. El hambre empuja hacia la migración, si hay expectativas de encontrar en ella remedio a esa tremenda e inminente angustia vital.

El hambre provoca también una sorda rebelión contra la propia existencia en libertad: “¡Ojalá hubiéramos muerto a manos del Señor en Egipto, cuando nos sentábamos junto a la olla de carne y comíamos pan hasta hartarnos!" (Ex 16, 3a). La olla de los trabajadores, esclavos forzados, es mejor que el hambre de 
los libertados en su largo camino hacia la tierra prometida. El hambre provoca rebelión también incluso contra quienes han sido líderes de la gesta de liberación de un pueblo esclavizado y sometido a trabajos forzados y a una política de genocidio: "La comunidad de los israelitas protestó contra Moisés y Aarón en el desierto, diciendo: "Nos han sacado a este desierto para matar de hambre a toda esta comunidad" (Ex 16, 2-3b).

Lo mismo pasa con la falta de agua. La sed angustia y enloquece. En su interminable caminar el pueblo israelita acampa en un oasis paradójicamente sin agua. "El pueblo, sediento, protestó contra Moisés: ¿Por qué nos has sacado de Egipto para matarnos de sed a nosotros, a nuestros hijos y al ganado?" (Ex 17, 3). En Babilonia, en pleno destierro, lo más duro en que pueden pensar los desterrados como castigo por olvidarse de Jerusalén es la sed: "Si me olvido de ti, Jerusalén [...], que se me pegue la lengua al paladar, si no te recuerdo" (Sal 137, 5-6).

En el Antiguo Testamento el hambre aparece también en otro contexto importante. Cuando el libro del profeta Isaías (el desconocido Trito Isaías) habla del ayuno que hace la gente satisfecha para congraciarse con Dios, deja resonar el gran clamor de denuncia: estás ayunando litúrgicamente y a tu alrededor gime la gente condenada a la opresión y al hambre. Ese ayuno es un insulto a las preferencias del Señor: "El ayuno que yo quiero es éste: abrir las prisiones injustas, hacer saltar los cerrojos de los cepos, dejar libres a los oprimidos, soltar todos los cepos, partir tu pan con el hambriento, hospedar a los pobres sin techo, vestir al que ves desnudo, y no cerrarte a tu propia carne" (Is 58, 6-7). Comenta L. A. Schökel: "en la propia carne se ha de sentir la necesidad del prójimo"1. Y prosigue el texto: "Entonces romperá tu luz como la aurora, en seguida te brotará la carne sana, te abrirá camino tu justicia, detrás irá la gloria del Señor [...] Si das tu pan al hambriento y sacias el estómago del indigente, surgirá tu luz en las tinieblas, tu oscuridad se volverá mediodía" (Is 58, 8.10).

Por eso, muchos siglos más tarde podrá decir San Ireneo: "La gloria de Dios es la vida del hombre". Es cierto que el texto continúa literalmente: "y la vida del hombre es la visión de Dios". Pero no sería bien comprendido si no incluyera centralmente que la vida digna de las personas es la gloria de Dios. Y que dar gloria a Dios es compadecerse entrañablemente de la miseria que deja a las personas "medio muertas" en el camino de la vida, y actuar con ellas como lo hizo el samaritano.

El mismo profeta formula el juicio y la sentencia finales como triunfo de las víctimas sobre los verdugos, pero lo hace en estos términos tan humanos: "Por eso, así dice el Señor: 'Miren: mis siervos comerán y ustedes pasarán hambre; miren: mis siervos beberán y ustedes tendrán sed" "(Is 65, 13ab). Y de ahí bro-

1. En nota de L. A. Schökel, La Biblia del peregrino, EGA-Mensajero, Bilbao, p. 939. 
tará la alegría o el sufrimiento: "miren: mis siervos estarán alegres, y ustedes avergonzados; miren: mis siervos cantarán de puro contento, y ustedes gritarán de puro dolor y aullarán con el corazón desgarrado" (Is 65, 13c-14).

Se trata de un juicio escatológico, que llevará consigo una nueva creación, entendida todavía en términos muy terrenos: "Miren: yo voy a crear un cielo nuevo y una tierra nueva [...] Ya no habrá allí niños malogrados ni adultos que no colmen sus años [...] Construirán casas y las habitarán, plantarán viñas y comerán sus frutos; no construirán para que otro habite, ni plantarán para que otro coma" (Is $65,17.21-22$ ). Se vislumbra que se hará realidad el sueño de la persona que trabaja y es mal pagada, y no puede dar a su familia ni a sí misma el alimento necesario. Se malogran sus hijos malnutridos. Ella misma pasa hambre y no tiene cómo pagar el precio de su vivienda.

Por eso, Isaías sueña la escatología, lo de más allá, el final, lo último, de esta manera: "El Señor de los Ejércitos of rece a todos los pueblos en este monte un banquete de manjares suculentos, un festín de vinos añejados, vinos generosos" (Is 25,6 ). Este banquete, que librará de las angustias del hambre y de la sed, librará además de la ansiedad del final, del fantasma de la muerte, de la que se ha estado tan cerca precisamente por el hambre y la sed, y de todo el sufrimiento que la rodea: "Arrancará en este monte el velo que cubre a todos los pueblos, el paño que tapa a todas las naciones; y aniquilará la muerte para siempre. El Señor enjugará las lágrimas de todos los rostros y alejará de la tierra entera el oprobio de su pueblo; lo ha dicho el Señor" (Is 25, 7-8).

Para leer bien hoy estos textos hay que procurar leerlos con el pathos, es decir, con la pasión con fueron escritos.

\subsection{En el Nuevo Testamento}

En el Nuevo Testamento nos encontramos con la misma pasión. Una vez más la experiencia terrible del hambre y de la sed, de la falta de techo, es decir, de la miseria, surgen como parámetro del juicio final, el juicio de "todas las naciones" (panta ta ethne). Aquí la perspectiva es distinta. No se habla en directo de los pobres, es decir de los miserables que viven en extrema pobreza, en enfermedad y opresión, en extrañamiento y marginación de la vida social o de la patria. Se habla, más bien, del modo de comportarse con ellos. "Vengan, benditos de mi Padre, a heredar el reino preparado para ustedes desde la creación del mundo, porque tuve hambre y me dieron de comer, tuve sed y me dieron de beber, era emigrante y me acogieron, estaba desnudo y me vistieron, estaba enfermo y me visitaron, estaba encarcelado y vinieron a verme" (Mt 25, 34-36).

Al escuchar estas palabras hoy, es preciso dejar que, como suele decirse, la imaginación llegue al poder en nosotros. Es preciso dejar que nos invadan las imágenes horrendas de mujeres con sus pechos caídos, de los cuales cuelgan 
niños escuálidos sin futuro. Es preciso revivir las largas filas de mujeres con sus cántaros sobre su cabeza, haciendo cola para traer agua del chorro público del barrio que sólo fluye dos o tres horas al día, mientras a su lado pasan camiones de agua embotellada con precios impagables para ellas. Es preciso revivir los caminos de la migración al Norte que se vuelven auténticos viacrucis, y encararse con los cadáveres regados en el desierto de Arizona, o la invasión por "la migra" y los federales de esas plantas de carne donde trabajan cientos de gentes sin papeles. Es preciso revivir los hospitales nacionales sin camas suficientes, sin sábanas en las camas, donde, para que los médicos y enfermeros atiendan, hay que llevar los medicamentos que cuestan - por ejemplo en El Salvador - el $500 \%$ de lo que cuestan en los países vecinos. Es preciso, finalmente, revivir las cárceles y penitenciarías inconcebiblemente hacinadas, donde el Estado pretende hacer pagar la delincuencia - sobre todo la de los pobres y marginados - y donde se provocan conflictos que acaban en asesinatos masivos, como en Pavoncito, en Guatemala, o en Honduras, en años recientes, para no hablar de Brasil o de Venezuela.

A quienes se preocupan por esas personas hundidas en la miseria es a quienes Jesús llama benditos de su padre y les dice que el reino ha sido preparado para ellos desde la creación. Y les dice, además, que al hacerlo se han preocupado por él mismo, se han encontrado con él, de modo que esas personas miserables son ya para siempre los rostros sufrientes de Jesucristo resucitado. ¡Tremenda paradoja! Para nuestro propósito es importante recordar que los dos primeros tipos de personas de las listas son los hambrientos y sedientos.

Jesús aparece ya "en su gloria", sentándose "en el trono de su gloria", es decir, como "rey" (Mt 25, 31.34). Pero ese rey es el mismo a quien el evangelio ha llamado en su existencia terrena "este hombre" o "el Hijo del hombre" (Mt 25, 31), el mismo que ha anunciado la cercanía del reino (Mc 1, 14), la necesidad de privilegiar en la vida de discipulado la búsqueda del reino y de su justicia (Mt 6,33), y la posibilidad de entrar en el reino con la gracia poderosa de Dios, venciendo la adicción idolátrica por la riqueza (Mc 10, 23-27), la realidad de que el reino de Dios está ya en medio de nosotros (Lc 17, 21), y la confianza de que, comprometiéndonos con todo lo anterior, el reino de Dios vendrá $(\operatorname{Lc} 11,2)$. Es el mismo Jesús que en su vida terrena "pasó haciendo el bien y curando a los poseídos por el diablo" (Hch 10,38), es decir, buscando la justicia del Reino. El mismo que contó la parábola del banquete para los pobres y lisiados, es decir, para los hambrientos y sedientos, sus convidados privilegiados (Lc 14, 15-23). Y el mismo a quien se le conmovieron las entrañas ${ }^{2}$ al ver a una multitud

2. Esplagchnisthe, del verbo splagchnistsesthai, que etimológicamente significa conmoverse las entrañas (splagchna = víscera, entrañas), y que puede traducirse también como enternecerse. Es la palabra con que el evangelista designa la emoción del samaritano al encontrarse al hombre asaltado y abandonado medio muerto en el camino 
hambrienta, que le había seguido durante un día entero para escuchar su buena noticia (Mc 6, 34 y 8,2) y decidió satisfacer el hambre de aquella gente.

\section{La Eucaristía en el contexto del hambre y la sed en el mundo}

No es extraño, pues, que quisiera que lo recordaran en el contexto de una comida de fiesta, el tipo de celebración que Jesús había preferido para significar su compromiso con los pobres y los marginados de "la mesa compartida" por su pecado público o por su implicación en actividades odiadas o despreciadas.

No es extraño, por lo tanto, que "la Cena del Señor", que anunciaba "la muerte de Jesús hasta que venga" (1Cor 11,26$)$ se celebrara como "fracción del pan" (Hch 2, 42.46) ${ }^{3}$, algunas veces en el contexto de un ágape o comida (Hch $2,46 ; 1$ Cor $11,17-22)^{4}$. Witherington describe así el contexto del relato más antiguo de la cena del Señor:

Oímos hablar aquí de divisiones que surgen en un acto de culto cristiano, es decir, en una comida de amistad, que era el contexto donde se participaba en la Cena del Señor. Estas divisiones parecen haber sido provocadas por miembros acomodados de la comunidad, que consideraban el banquete de amistad como una fiesta privada, tal vez un banquete seguido por otra fiesta con bebidas [o tragos] (convivium). El resultado era que la estratificación social de la comunidad se subrayaba exageradamente y quedaba exacerbada. ${ }^{5}$

Pablo no oculta la muy probable ${ }^{6}$ estratificación social de la "Iglesia de Dios en Corinto" (1Cor 1,2$)$. Habla de una minoría de "sabios $[\ldots]$, poderosos $[\ldots]$ y de buena familia", y de una mayoría de "locos para el mundo [...], débiles del mundo $[\ldots]$ y de condición plebeya y despreciada por el mundo", que, además, se convierten en símbolo de la confusión y rechazo que provoca el anuncio paulino de un Mesías crucificado, "escándalo y locura", y del cambio de suerte que Jesús, el Mesías crucificado, ha significado para todos los miembros de la comunidad (1Cor 1, 26-31).

(Lc 10, 33), y también la misma palabra cuando se describe la emoción que Jesús sintió al encontrarse con la viuda de Naín que había perdido a su hijo único (Lc 7,13$)$. Sobre todo es la palabra que describe la emoción del padre del hijo pródigo cuando lo ve de lejos regresando al hogar en harapos y medio muerto de hambre (Lc 15, 20).

3. Joseph A. Fitzmyer, Los Hechos de los Apóstoles, Hch 1, 1-8, 40 (vol. I), Salamanca, 2003, p. 367. La frase "partir el pan" o "fracción del pan" se había convertido pronto en una forma abstracta de referirse a la celebración de la Cena del Señor: “¿El pan que partimos no es comunión con el cuerpo de Cristo?" (1Cor 10, 16).

4. Ibid., p. 369.

5. Ben Witherington III, Conflict and community in Corinth: A Socio-Rhetorical Commentary on 1 and 2 Corinthians, Grand Rapids, Michigan, 1995, p. 241.

6. Una minoría de exegetas piensa que las diferencias que vamos a citar son lenguaje irónico de Pablo más que reales. 
Por otra parte, Pablo intenta directamente subvertir esa estratificación con una propuesta socialmente revolucionaria que la convirtiera en lo que otros escritos del Nuevo Testamento indican que fue la primitiva comunidad de Jerusalén: "los creyentes estaban todos unidos y poseían todo en común; vendían bienes y posesiones y las repartían según la necesidad de cada uno" (Hch 2, 44-45) ${ }^{7}$. Lo que Pablo hace es enunciar una propuesta radical de fraternidad e igualdad, fundamentada en la unidad de todos quienes creen en Cristo, propuesta que fuera minando lentamente las profundas desigualdades en las culturas contemporáneas: "Ya no se distinguen judío y griego, esclavo y libre, hombre y mujer, pues en Cristo Jesús todos son uno" (Gal 3, 28) ${ }^{8}$. "Pablo esperaba que la comida que comparten los cristianos fuera más igualitaria".

No debe, pues, extrañarnos que Pablo reaccione con indignación frente a los excesos en el comer y en el beber, que dividen la comunidad eclesial de Corinto y destruyen incluso la solidaridad eucarística. Pablo arguye que es intolerable que, mientras "unos se adelantan a consumir su propia cena y se emborrachan, otros pasan hambre". Eso lo ha conseguido ia privatización de la comida de amistad, previa a la cena del Señor. Por eso "Pablo se pone de parte de los pobres y débiles, y arguye contra los poderosos y ricos" ${ }^{0}$ : “No tienen casas para comer y beber? ¿Menosprecian la asamblea de Dios y avergüenzan a los que nada poseen? ¿Qué puedo decirles? ¿Voy a alabarlos? En esto no los alabo" (1Cor 11, 22).

7. Este casi comunismo cristiano de la comunidad eclesial jerosolimitana ha sido exegetizado no pocas veces como una "descripción idílica", en vista de los conflictos que surgen en los capítulos 5 y 6 de los Hechos, aunque el mismo Fitzmyer presenta otras opiniones menos tajantes. La descripción de Hch 4, 32-35 es, si cabe, más radical; cf. Fitzmyer, óp. cit., pp. 363, 369, 424-427. Antonio González presenta un amplio estado de la investigación, citando especialmente a Theissen, Meeks, Aguirre y Stegemann sobre la composición social de las primeras comunidades cristianas, y a Drexhage, Meeks, Holmberg, etc., sobre el "comunismo cristiano"; además, él mismo estudia los datos y da su propia opinión, cf. Reinado de Dios e Imperio. Ensayo de teología social, Santander, 2003, pp. 201-247.

8. No cabe duda de que esta propuesta de fe - y la fe es también praxis - contribuyó a suprimir casi totalmente la esclavitud como modo de producción económico en el mundo cristiano de occidente. Aunque no impidió a los cristianos, pocos siglos después, promover la trata de personas negras africanas y aprovecharse luego de la fuerza de trabajo de los esclavos. Ni tampoco fue suficiente para despatriarcalizar el mundo occidental cristiano. Lo cual puede significar que la igualdad étnica (donde la raza suele jugar un papel) y la igualdad de género son palabras mayores que la igualdad económica, aunque esta vuelve a corromperse a través de aquélla, sobre todo cuando lo étnico evoluciona hacia lo nacional.

9. Witherington III, óp. cit., p. 242.

10. Ibid., p. 248. 
Pablo no puede tolerar que los pobres sufran hambre y vergüenza justo antes de la Eucaristía. Por eso, va más allá del reproche y "afirma categóricamente que, al faltar la caridad, al romperse la unidad de la asamblea, el rito no es 'la Cena del Señor"" no comen la cena del Señor" (1Cor 11, 20).

\subsection{La globalización de la experiencia del hambre y la sed, y la eucaristía. Testimonios}

Pablo habla en un contexto donde el Imperio romano ha impuesto la Pax romana, la "paz con derramamiento de sangre", como decía el historiador romano Tácito. El mundo del poder romano, el mundo de la cultura grecorromana, con sus calzadas protegidas y vigiladas a la vez por las legiones militares, había acortado las distancias geográficas y humanas, pero nada tenía que ver aún con lo que hoy llamamos globalización, donde el mundo se ha convertido en una "aldea planetaria". Por eso, hoy el contexto de la eucaristía no es local, ni siquiera únicamente nacional, sino también global. La eucaristía, aun aquella que se celebra en la más remota y pequeña comunidad, tiene dimensiones "gloncales", es decir, globales, nacionales y locales, como dijo el jesuita Xabier Gorostiaga. Y hoy el hambre en el mundo, en Haití o en Nicaragua, en Benín o en el Chad, en Zimbabue o en Malaui, en Níger o en todo el Sahel, en Timor Oriental o en Myanmar, es también nuestra vecina. O mejor, son nuestros vecinos y vecinas las personas que sufren hambre y sed en todo el planeta, y las que la sufren en nuestra vecindad, en los Nonualcos o en Perquín ${ }^{12}$, en Tajumulco o en Camotán ${ }^{13}$. No podemos celebrar la eucaristía sin que se nos conmuevan las entrañas como se le conmovieron a Jesús. La Eucaristía del lujo y del esplendor tiene sobre sí el clamor de los dos mil millones de personas con hambre en el mundo y sin acceso a agua potable. Veamos algunos testimonios.

\subsubsection{E1 Padre Arrupe}

En el Congreso Eucarístico de Filadelfia en 1976, el P. Pedro Arrupe, entonces General de los jesuitas, se expresó así:

Este redescubrimiento de lo que podría ser llamado la 'dimensión social' de la Eucaristía, tiene hoy un significado enorme. Una vez más vemos la santa Comunión como el sacramento de nuestra fraternidad y unidad. Nosotros compartimos el mismo alimento comiendo el mismo pan junto a la misma mesa. Y san Pablo nos dice claramente: "Puesto que es uno solo el Pan, nosotros, aun siendo muchos, somos un solo cuerpo: Todos, en efecto, par-

11. Schökel, óp. cit., p. 1968, nota a 11, 20.

12. Pueblos de E1 Salvador.

13. Municipios de Guatemala. 
ticipamos del único Pan" (1Cor 10, 27). En la Eucaristía, en otras palabras, recibimos no sólo a Cristo, la Cabeza del cuerpo, sino también a sus miembros...

Debería $[\ldots]$ ser evidente por qué un simpósium sobre el hambre pueda ser parte integrante y fundamental de un congreso eucarístico internacional. Hace doce años, en su saludo inaugural al Seminario para la alimentación y la salud que formaba parte del XXXVIII Congreso Eucarístico Internacional de Bombay, el Cardenal Gracias dijo: "Pretender unir a todos los hombres en la participación de un Pan espiritual sin proveerles al mismo tiempo de pan material, es únicamente un sueño". ${ }^{14}$

\subsubsection{E1 P. Alberto Hurtado}

Dos grandes santos del siglo XX, uno canonizado, Alberto Hurtado, S.J., de Chile, y la otra, laica de una integridad admirable y de una compasión sin límites, Dorothy Day, de los Estados Unidos, coincidieron en la fundación de hogares para la gente hambrienta, desempleada, vagabunda, sin esperanza: el "Hogar de Cristo" y los hogares del "Catholic Worker" ("el Obrero Católico"). Cuatro días antes de su muerte por cáncer, Hurtado escribe:

Al partir, volviendo a mi Padre Dios, me permito señalarles un último anhelo: el que se trabaje por crear un clima de verdadero amor y respeto al pobre, porque el pobre es Cristo. "Lo que hiciereis al más pequeñito, a mí me lo hacéis" (Mt 25, 40). El Hogar de Cristo, fiel a su ideal de buscar a los más pobres y abandonados para llenarlos de amor fraterno, ha continuado con sus Hospederías de hombres y mujeres, para que aquellos que no tienen dónde acudir, encuentren una mano amiga que los reciba. ${ }^{15}$

Más de veinte años después de su muerte, durante la cruel dictadura de Pinochet, la Vicaría de la Solidaridad en Santiago dio a la intuición de Alberto Hurtado un alcance arquidiocesano y nacional de mesa compartida para los pobres sospechosos y privados de su sueño.

\subsubsection{Dorothy Day}

Dorothy Day aún no está canonizada, por su postura radicalmente pacifista, llena de denuncia de la bomba atómica lanzada sobre Hiroshima y del rearme durante la Guerra Fría. En el mismo congreso eucarístico de Filadelfia, donde

14. Pedro Arrupe, S.J., "Eucaristía y Hambre en el Mundo", en La Iglesia de hoy y del futuro, Bilbao-Santander, Mensajero-Sal Terrae, 1982, pp. 384-385.

15. Alberto Hurtado, S.J., Un fuego que enciende otros fuegos. Páginas escogidas, Santiago, Centro de Estudios y Documentación "Padre Hurtado" de la Pontificia Universidad Católica de Chile, 2004, p. 181. 
habló el P. Arrupe, también a Dorothy Day le pidieron que hablara, y que hablara sobre "las mujeres en la Iglesia". Con su acostumbrada libertad, no habló sobre eso. Habló del amor de Dios y de la necesidad de llevar ese amor a toda la creación: "mi conversión comenzó [...] en un tiempo cuando el mundo material comenzó a hablarme en mi corazón del amor de Dios".

Habló de la Iglesia y afirmó que su amor y gratitud hacia ella habían aumentado con los años: "ella me enseñó la cumbre del amor en la vida del Espíritu". Luego se refirió a las ceremonias del día anterior en el Congreso, con las que se había honrado a las fuerzas armadas, y dijo que la Iglesia le había enseñado también que "antes de traer al altar nuestros dones de servicio o gratitud, si tu hermano tiene algo contra ti, debes pensarlo bien antes de acercarte al altar para recibir la Eucaristía". Y citó la escritura: "Si no hacen penitencia, todos perecerán". Recordó a su auditorio que aquel día era el 6 de agosto, día en que la bomba atómica fue lanzada sobre Hiroshima.

Después de haber recordado el genocidio contra los armenios y el holocausto contra los judíos, continuó: Jesucristo nos dijo que "todas las personas son hermanas, que su voluntad era que todas alcanzaran la salvación, fueran japonesas, judías o armenias". Y terminó diciendo: Dios "nos dio la vida, y la Eucaristía para alimentar nuestra vida. Pero nosotros hemos dado al mundo instrumentos de muerte de magnitud inconcebible". Había hablado con radicalidad a favor de la paz. La contradicción entre la Eucaristía, la guerra y su fruto más amargo, el hambre, era evidente ${ }^{16}$.

\subsubsection{Jean Ziegler}

Suizo, doctor en Economía por la Universidad de Berna, actual Relator Especial de Naciones Unidas para el Derecho a la Alimentación, a quien se le impidió la entrada en los Estados Unidos. Cuando quiso estudiar las consecuencias del embargo norteamericano contra Cuba, escribe que "más de $\mathbf{2}$ mil millones de seres humanos viven en lo que el Programa de las Naciones Unidas para el Desarrollo (PNUD) denomina la 'miseria absoluta', es decir, carecen de ingresos fijos, no tienen trabajo regular ni un lugar adecuado donde vivir; no cuentan con atención médica, ni disponen de alimentos suficientes, no tienen acceso al agua ni están escolarizados" ${ }^{17}$. Ziegler contestó así a preguntas que le hizo el diario español El País:

Pregunta. Usted dice que ahora [mayo 2005] 'hay 10 millones de personas más que en 2004, que pasan hambre en el mundo'.

Respuesta. En efecto. 100.000 personas mueren de hambre, o de sus consecuencias inmediatas, cada día. Un niño de menos de 10 años muere cada sie-

16. William D. Miller, Dorothy Day, a biography, New York, 1982, pp. 512-513.

17. Jean Ziegler, Los nuevos amos del mundo, Barcelona, 2003, p. 15. 
te segundos y cada cuatro minutos otro queda ciego por falta de vitamina A. El orden mundial no es solo asesino, sino absurdo, pues mata sin necesidad. Hoy ya no existen las fatalidades. Un niño que muere de hambre hoy, muere asesinado.

Pregunta. ¿Qué quiere decir exactamente 'pasar hambre', según los criterios de la ONU?

Respuesta. Hay dos tipos de hambre: el coyuntural y el estructural. El coyuntural es la hambruna a que estamos acostumbrados en Darfur, Etiopía o en periodos de guerra, y es fruto del hundimiento de una economía [por la guerra, por ejemplo]. Este tipo de hambre causa el 5\% de víctimas. Mientras que el hambre estructural es el implícito en las estructuras del subdesarrollo. Causa el $95 \%$ de las muertes y es el hambre que realmente pide a gritos la intervención de la comunidad internacional.

Pregunta. Usted ha afirmado que 'la malnutrición severa de niños menores de cinco años en Irak' se ha doblado entre junio de 2003 y septiembre de 2004. ¿Hay soluciones a la vista?

Respuesta. Lo terrible de esta situación, en Irak como en otras partes, es que el hambre se reproduce biológicamente. Cada año cientos de millones de mujeres dan a luz a cientos de millones de niños destruidos desde el momento mismo del nacimiento. Un niño subalimentado entre los cero y los cinco años ya no tiene arreglo. Incluso si a los seis años tiene suerte y lo adopta una familia española, está dañado de por vida...

Pregunta. ¿Estamos acercándonos a la guerra del agua? ¿Cómo ve el futuro de este vital recurso?

Respuesta. Hay mil millones de personas que no tienen acceso al agua potable no nociva, y no hay que olvidar que el agua destruye indirectamente a través de las enfermedades. En segundo lugar está el problema de la privatización del agua. En Bolivia o Filipinas nos encontramos con agua privatizada que aumenta de precio en un 400\%. Así, los pobres de Manila o Cochabamba no pueden pagar el agua de sus propios grifos.

Pregunta. ¿Entonces no hay salida?

Respuesta. El presidente Lula, de Brasil, ha creado el Programa Fome 0 (Hambre 0), que está sirviendo de modelo a diversos planes en [América Latina]. Tengo esperanza también en el Programa de Erradicación Mundial del Hambre [de la ONU]... [Sin embargo,] hasta aquí hemos vivido bajo la herencia de la época del poder por delegación, la república y los derechos humanos. Toda esta herencia está amenazada de muerte por el gran capital financiero internacional que pretende que la mano invisible del mercado es la única y suprema autoridad de la historia. Estamos creando un mundo en que 
los derechos humanos no tienen sitio y la propia democracia está en grave peligro; hasta el punto de que puede llegar a desaparecer. Es decir, vivimos en la jungla del capitalismo globalizado y la ley del más fuerte. Puede haber salida, pero debemos ser conscientes de que estamos defendiendo la última trinchera. $^{18}$

\subsection{La Eucaristía, celebración donde se escucha el clamor del hambre y de la sed}

En este contexto celebramos hoy la Eucaristía. La Eucaristía hace a la Iglesia. Y una de las formas como la hace es ofreciéndole - a las Iglesias que están en cada localidad y a la Iglesia universal, "comunidad de comunidades"- un Programa para la vida servicial en comunidad y en sociedad. Si la Eucaristía remite siempre, por su vinculación con el reino de Dios, a las comidas de Jesús con los pobres, los pecadores y aquellos que quedaron marginados o segregados de la mesa de la gente de posición alta y de prestigio; si la Eucaristía es, por la mediación de la última cena, memorial de Jesús crucificado, entonces es claramente una invitación a vivir en solidaridad con la gente crucificada de este mundo, y un desafío a bajarla de la cruz, para ser así seguidores del "cordero de Dios que quita el pecado del mundo" (Jn 1, 29). Si además la Eucaristía es la celebración de Jesucristo resucitado - el mismo que fue crucificado-, entonces el memorial eucarístico de la resurrección debe llegar a hablar simbólica, pero fuerte e inteligiblemente, de la vida como respuesta a toda civilización de la muerte. Nuestra eucaristía debe llegar a ser un clamor en medio del mundo a favor de la integración de las razas, las etnias y los pueblos, un clamor contra la enorme brecha de desigualdad que hoy polariza a nuestras sociedades, un llamado ineludible a la hospitalidad y a la convivialidad contra toda segregación y marginación, una convocatoria incondicional al banquete, una oferta de vestido nuevo, de enorme alegría y de fiesta para todos los injustos y pecadores, como la del padre del hijo pródigo.

Pero incluso así, nuestra eucaristía no puede perder nunca su carácter profético, porque al reiterar con el ritmo de la liturgia la última cena de Jesús, no puede dejar de hacer consciente al mundo de su pecado contra todas las víctimas y contra el mismo "pionero de su salvación" (Hbr 2, 10), que aprendió antes a ser salvador en la solidaridad del sufrimiento (Hbr 5, 8-9). Así, la Eucaristía de la Iglesia, misterio y sacramento de la fe, llegará a ser la mesa de la humanidad. La mesa de todos. Y si no se celebra así, más pronto que tarde, llegará a ser un rito intrascendente, despojado, además, de su valor sacramental $(1$ Cor 11, 20).

18. R. Carrizo Couto, “ “Un niño que muere de hambre muere asesinado”. Entrevista con Jean Ziegler, Relator de la ONU para la Alimentación", en E1 País, Madrid, lunes 9 de mayo de 2005, p. 40. Énfasis míos. 


\subsection{La miseria de la naturaleza: la tierra bajo ataque}

En el mundo actual, además, vivimos otra destrucción inigualable: la "destrucción de la naturaleza". Escribe Ziegler:

Entre todos los estragos que el capital financiero multinacional ha infligido a la naturaleza, tomemos por ejemplo la devastación de los bosques y selvas vírgenes del planeta [...] En la actualidad las selvas y bosques tropicales tan solo cubren el $2 \%$ de la superficie de la tierra, pero albergan más del $70 \%$ de todas las especies vegetales y animales del planeta. En el plazo de cuatro décadas, de 1950 a 1990 , la superficie global cubierta por bosques y selvas vírgenes se redujo en más de 350 millones de hectáreas, destruyéndose el $18 \%$ en la selva africana; el $30 \%$ de las selvas y bosques de Oceanía y Asia; el $18 \%$ de los bosques y selvas latinoamericanos y del Caribe. Se estima que en la actualidad cada año se destruyen más de tres millones de hectáreas. ${ }^{19}$

Basta este botón de muestra de la deforestación, sin que nos metamos con la emisión de gases destructivos, el cambio climático y otros problemas ecológicos. Es indudable que los destrozos humanos y naturales causados por la Tormenta Stan en Guatemala, en octubre de 2005, se debieron en muy buena parte a la depredación de los bosques provocada por la codicia de los madereros. Y lo mismo ocurrió en El Salvador en el terremoto de 2001 con los terribles aludes que enterraron a ochocientas personas en un proyecto habitacional de Santa Tecla, que, junto con otros, había dejado sin protección los montes de la cordillera del Bálsamo. Si pensamos en los terribles datos de muertes, desaparecimientos y derrumbes de edificios causados por los últimos terremotos en China, no cabe duda de que la depredación de bosques para construir las enormes presas hidroeléctricas hasta llegar a la gigantesca de las Tres Gargantas sobre el río Yangtsé-Qiang, son parte de la causa de la tragedia.

\section{Jesucristo en la tierra y la teología de la Eucaristía}

La Iglesia cristiana empezó muy pronto a reflexionar teológicamente sobre Jesucristo y su relación con la creación: "Todo existió por medio de ella [la Palabra] y sin ella nada existió de cuanto existe" (Jn 1,3). O también "él es la imagen del Dios invisible, primogénito de toda la creación, pues por él fue creado todo, en el cielo y en la tierra: lo visible y lo invisible... Todo fue creado por él y para él, él es anterior a todo y todo tiene en él su consistencia" (Col 1, 15-17). Pero, a pesar de que esta reflexión está en conexión inmediata con el puesto de Jesucristo en la Iglesia - "Él es la cabeza del cuerpo de la Iglesia, es el principio, primogénito de los muertos, para ser el primero de todos" (Col 1, 18) -, sin embargo en la Iglesia no hemos relacionado la Eucaristía muchas veces con la naturaleza creada. Dice Ireneo:

19. Jean Ziegler, óp. cit., p. 138. 
Las creaturas es él quien nos las da, haciendo salir su sol y haciendo 1lover como quiere. Él proclamó que el cáliz que procede de la creación es su propia sangre, con la cual irriga la nuestra. Y él confirmó que el pan de la creación es su propio cuerpo con el cual da incremento a nuestros cuerpos... Y así como el tronco de la vid puesto en la tierra da fruto en el tiempo apropiado, y el grano de trigo, al caer en la tierra y descomponerse, surge multiplicado por el Espíritu de Dios, que mantiene todas las cosas, de suerte que luego por la sabiduría de Dios puede ser puesto a uso del hombre, y recibiendo la palabra de Dios se convierte en la Eucaristía, que es el cuerpo y la sangre de Cristo, así también nuestros cuerpos que se alimentan con ella, resurgirán a su propio tiempo, cuando la palabra del Señor les haga el don de la resurrección para gloria de Dios Padre. ${ }^{20}$

La reflexión de Ireneo refleja una de las fórmulas eucarísticas de la más temprana Didakhé:

Como este fragmento estaba disperso sobre los montes, y reunido se hizo uno, así sea reunida tu Iglesia de los confines de la tierra en tu reino... Tú, Señor omnipotente, creaste todas las cosas por causa de tu nombre, y diste a los hombres alimento y bebida para su disfrute, para que te dieran gracia. Mas a nosotros nos hiciste el don de un alimento y una bebida espiritual y de la vida eterna por medio de tu siervo. ${ }^{21}$

Modernamente ha sido Pierre Teilhard de Chardin quien, en esa misma tradición, vibró con inmensa y profunda sensibilidad con la tierra y la puso en relación con la Eucaristía:

Verbo resplandeciente. Potencia ardiente, Tú que amasas lo Múltiple para infundirle tu vida, abate sobre nosotros, te lo ruego, tus manos poderosas, tus manos previsoras, tus manos omnipresentes...

Prepara con esas manos invencibles, mediante una adaptación suprema, para la gran obra que proyectas, el esfuerzo terrestre cuya totalidad te presento en este momento concentrada en mi corazón. Reestructura este esfuerzo, rectifícale, refúndele hasta en sus orígenes, tú que sabes por qué es imposible que la criatura nazca de otra forma que no sea sostenida sobre el tallo de una interminable evolución.

Y ahora pronuncia, utilizando mi boca, la doble y eficaz palabra sin la cual todo se bambolea, todo queda al descubierto en nuestra sabiduría y en nuestra experiencia: con la cual todo se concentra y todo se consolida indefinidamente en nuestras especulaciones y nuestra práctica del Universo. Repite sobre toda vida que va a germinar, a crecer, a florecer y a madurar en este

20. En José Vives, Los Padres de la Iglesia, Barcelona, Herder, 1988, pp. 199-200.

21. Ibid., pp. 20-21. 
día: "Este es mi cuerpo". Y sobre toda muerte que se apresta a roer, a ajar, a cortar, ordena (¡misterio de fe por excelencia!): "Esta es mi sangre”. ${ }^{22}$

Obviamente la Eucaristía con y por la naturaleza, no puede quedarse en consagración, sino que tiene que acercarse a ser comunión también. De ello habla alguien, en la mejor tradición franciscana, con gran ímpetu poético, a propósito de "abrazar árboles".

Cabía entero en mis brazos. Abracé al árbol con cariño como quien lo despierta de su propio ensimismamiento. Después con más fuerza. Y por fin con toda mi fuerza, como quien quisiese mezclarse con él. Por fin encontré el ritmo que me parecía adecuado en un acto de comunión... Lentamente me fui convirtiendo en árbol. Mi cabeza se transformó en copa, mis cabellos en hojas, mi tronco en tronco, los brazos en muchas ramas y mis pies en raíces que penetraban por el suelo. Sentía una energía bienhechora que venía del cielo y subía por la tierra, transmitiendo energía a todo mi ser. De repente no me sentía más yo. Era pura energía cósmica y vital. El árbol era yo. Yo era árbol... ¿Dónde estaba? ¿Quién era? ¿Qué había sucedido en ese sueño sin dormir? Estaba paralizado. Pero profundamente reconciliado y sereno... Le hablé espontáneamente: “¡Árbol, hermano mío, háblame de la energía que te posee! ¡Háblame de la fuerza que te habita! ¡Revélame tu misterio telúrico y uránico, ya que tus pies se sumergen en la tierra y tu cabeza penetra en el cielo! ¡Háblame de ti!". Los árboles, como todas las mujeres, adoran ser seducidos con bellas palabras y tonos encantadores. Pero solo se entregan, como las mujeres, cuando sienten que la palabra no es instrumento de seducción, sino señal de comunión y ternura... El árbol comenzó a expresarse... Sus hojas comenzaron todas a balancearse. Lentamente al principio. Después con más frenesí. Por fin era un océano de hojas que se movían como olas que iban y venían, en un griterío de aguas de cascada, brillando al sol que se filtraba como antorchas a través de ellas. Por fin era la copa entera que meneaba la cabeza ora hacia adelante, ora hacia atrás, ora en círculo, dando a entender que expresaba gran regocijo. Yo lo incentivaba cariñosamente: “¡Háblame, hermano! ¡Canta, querido! ¡Sonríe, amor mío! ¡Dimmi tutto, tutto!". Entonces sucedió algo maravilloso. Se cubrió todo de flores. Al principio blancas, después color de rosa, amarillas, anaranjadas, rojas...". Yo le repetía: Hermanito querido, aimmi tutto, di todo, todito, habla de ti, revela tu presencia, entrega tu misterio. Entonces las flores comenzaron a caer como cascada de soles despedazados, oro y plata. El suelo parecía un rosetón de catedral. Y en todo lo alto, en el ramaje..., frutos, frutos y más frutos. Cerré los ojos para ver mejor. Me quedé así largo tiempo. El árbol comenzó a cre-

22. Pierre Teilhard de Chardin, "La Misa sobre el mundo", en Himno del Universo, Madrid, Taurus, 1964, pp. 20-21. 
cer dentro de mí... Ya no era yo... Yo era nuevamente árbol. Quedé eternamente así, extasiado en un tiempo sin secuencia. La mente totalmente vacía sintonizaba con la tierra y con el cielo. Todo lo demás no tiene nombre. Nada que pueda ser narrado. Todavía hoy cuando paso por allí siento que aquel lugar es sacramental...

Cuando tú, lector, y tú, lectora, te sientas vacío, lejos de tu propio centro, desvitalizado por el exceso de preocupaciones y de intimidaciones de la vida urbana o de tus quehaceres, busca la fuerza escondida en los árboles... Comienza siempre por la respiración. Ella despierta en ti tu dimensión mágica, pues te coloca en contacto con las energías cósmicas. Por ellas el Espíritu Santo te penetra, el Spiritus semper creator que nos llena de entusiasmo. Es nuestro Dios interior, la brasa que siempre arde. Y la respiración creará un puente entre tú, el árbol y el Espíritu. Y celebrará un esponsal cósmico. Abrázale, acaríciale, háblale palabras de amor y de comunión. Hasta que tú mismo te conviertas en árbol. Saldrás sereno y entusiasmado. Sentirás un Dios habitando tu ser. Pasarás del Dios que tienes al Dios que eres, en la más profunda intimidad, allí donde todos somos misterio, el nombre verdadero de Dios.

Si Dios está con nosotros, ¿quién podrá estar contra nosotros? ¡Es fantástico! Hermanas y hermanos, yo vi, sentí, viví y testifico que lo fantástico es real y lo real es fantástico. ${ }^{23}$

El encuentro eucarístico con la naturaleza que acabamos de transcribir es sencillamente una de las muchas maneras que Jesucristo resucitado, el mismo que fue crucificado, tiene de cumplir su promesa: "Y yo estaré con ustedes todos los días hasta el fin del mundo" (Mt 28, 20).

Lo mismo encontramos en la tradición carmelitana:

Pastores los que fuerdes

Allá por las majadas al otero,

Si por ventura vierdes

aquel que yo más quiero,

decidle que adolezco, peno y muero.

Buscando mis amores

Iré por esos montes y riberas;

Ni cogeré las flores,

Ni temeré las fieras,

$\mathrm{Y}$ pasaré los fuertes y fronteras.

23. Leonardo Boff, "Abrazar árboles", en Brasas bajo las cenizas. Historias anticotidianas del mundo y de Dios, Madrid, Trotta, $2^{\mathrm{a}}$ ed., 1998, pp. 74-77. 
¡Oh, bosques y espesuras

Plantadas por la mano del Amado;

Oh, prado de verduras

De flores esmaltado,

Decid si por vosotros ha pasado!

Mil gracias derramando

Pasó por estos sotos con presura,

E, yéndolos mirando,

Con sola su figura

Vestidos los dejó de su hermosura. ${ }^{24}$

Nadie sabe qué habría hecho hoy San Juan de la Cruz frente a la triste depredación de todos esos paisajes que le inspiraron para llegar hasta la expresión de su encuentro místico con Dios.

Parecida sensibilidad, aunque más sobriamente o más prosaicamente, se encuentra en la tradición ignaciana, por ejemplo en la "Contemplación para alcanzar amor":

Mirar cómo Dios habita en las criaturas, en los elementos dando ser, en las plantas vejetando, en los animales sensando, en los hombres dando entender; y así, en mí dándome ser, animando, sensando y haciéndome entender; asimismo haciendo templo de mí siendo criado a la similitud e imagen de su divina majestad...

Considerar cómo Dios trabaja y labora por mí en todas cosas criadas sobre la haz de la tierra, id est, habet se ad modum laborantis (es decir, se porta como quien trabaja). Así como en los cielos, elementos, plantas, fructos, ganados, etc., dando ser, conservando, vejetando y sensando, etc.

Mirar cómo todos los bienes y dones descienden de arriba, así como la mi medida potencia de la summa y infinita de arriba, y así justicia, bondad, piedad, misericordia, etc., así como del sol descienden los rayos, de la fuente las aguas, etc. ${ }^{25}$

Al fin de sus días, siendo primer General de la Compañía de Jesús, dicen sus contemporáneos que salía al jardín de su casa en Roma y con su bastón golpeaba las flores diciéndoles: "No me hablen tan fuerte, ya sé de quién me hablan". E igualmente, en las noches se extasiaba contemplando el cielo romano en sus días veraniegos llenos de estrellas.

24. San Juan de la Cruz, "Canciones entre el alma y el esposo", en Obras Completas, Madrid, BAC, 1982, pp. 25-26.

25. San Ignacio de Loyola, "Ejercicios espirituales", en Obras Completas, Madrid, BAC, 1963, p. 244. 
Así como no puede celebrarse hoy la Eucaristía sin el telón de fondo del hambre y la sed en el mundo, tampoco puede haber Eucaristía hoy en que no celebremos proféticamente el dolor de la creación mutilada por nosotros, y la alegría de la creación, cantada siempre por los poetas y los santos, y resucitada hoy por la lucha de las personas ecologistas, por Green Peace y tantos otros movimientos que luchan a favor de la Tierra, y así también a favor del Primogénito de la Creación y Primogénito de los muertos, para que, desde la Eucaristía, la Iglesia se aproxime a ser el hogar de libertad y justicia, de verdad y de amor cuya acción creíble, eucarística - litúrgica y místico-ética-contribuya a que la Eucaristía llegue a ser símbolo de fraternidad y sororidad con la humanidad y con la naturaleza heridas. 